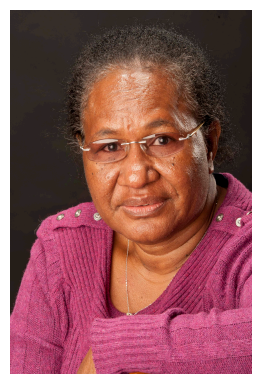

\title{
THE GOVERNANCE OF NATURAL RESOURCES: ISSUES AFFECTING BETTER MANAGEMENT OF REVENUES AND DISTRIBUTION OF BENEFITS WITHIN PAPUA NEW GUINEA
}

\author{
Hitelai Polume-Kiele \\ Doctoral candidate \\ Australian Centre for Agriculture and Law \\ School of Law \\ University of New England
}

\begin{abstract}
Papua New Guinea is rich in natural resources, including minerals, oil, gas, timber and fish, and cash crops such as coffee, palm oil, cocoa, copra, rubber, tea and spices which contribute significantly to Papua New Guinea's overall development. Several mining, oil and gas companies are currently operating in Porgera, Ok Tedi, Lihir, Hidden Valley, Sinivit, Simberi, Tolukuma, Kutubu and Gobe. The operations of these companies have generated an estimated K13.42 billion to Papua New Guinea's economy. Landowners affected by these developments also receive royalties from those operations. However this wealth has not been translated into tangible human development across the country, as shown in persistently poorly performing social indicators. Instead income from the exploitation of natural resources is being used in unplanned projects and not focused on the delivery of core social functions, such as the provision of a stable and non-distorting policy aimed at building and sustaining the development of a modern market, and legislative and regulatory frameworks, social services, social security and social infrastructure which would lead to the improvement in the delivery of essential services to all Papua New Guineans. There is widespread evidence of benefits not being distributed to all landowners. Landowners are yet to fulfil their aspirations regarding these developments and to see improvements in their living standards. This paper discusses two case studies: the Porgera and Lihir mines, outlining the landowners associations' experiences, which illustrate issues of governance and management of the distribution of benefit flows from the exploitation of Papua New Guinea's natural resource wealth.
\end{abstract}

The focus of the article's discussion is on governance and management issues that affect the distribution of benefits, delivery of essential services to rural areas of PNG, stability within government, and the expectations of landowners.

\section{Introduction}

According to the law of Papua New Guinea (PNG), the state owns all the country's land ${ }^{1}$ and water, $^{2}$ including mineral $^{3}$ and petroleum ${ }^{4}$ resources. However, PNG landowners do not accept this law. They have difficulties in reconciling this concept of ownership with their customary/traditional way of life ${ }^{5}$ which maintains that the clan should be the primary arbiter of ownership, and any issuance of leases over land for resource development should require the consent of the landowning communities. ${ }^{6}$ The clans, in most cases, hold a strong bargaining position in negotiations over resource ${ }^{7}$ developments, and demands for compensation is firmly on their agenda. Landowners receive 40 per cent of benefits flows including: (i) mitigation projects - in funding provisions for social infrastructure, such as schools, health services (aid-posts) and roads; (ii) first preferences for employment; (iii) project community relations extension support in the field of primary health care, business development and land mobilisation; (iv) enhanced education and training opportunities, and

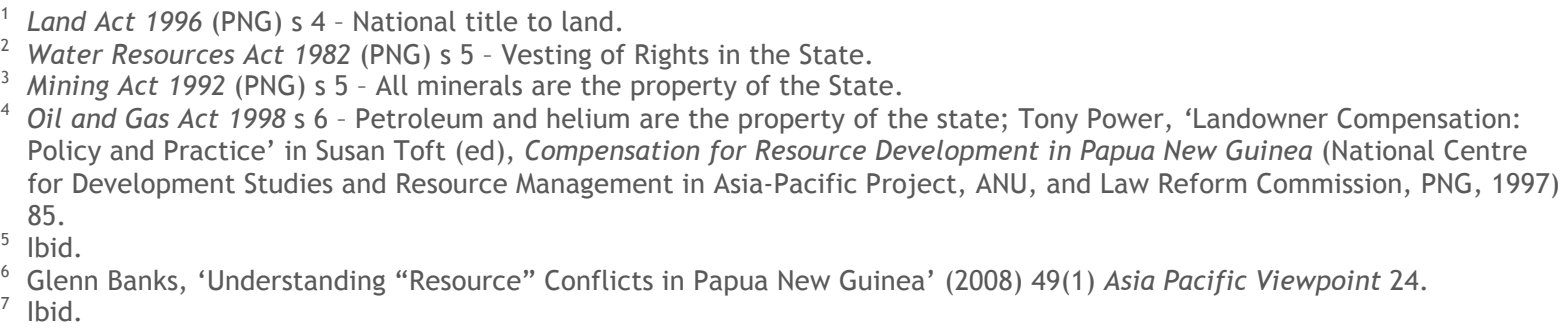


support for cultural and sporting activities; and (v) preferential treatment of landowner companies for business spin-offs. ${ }^{8}$

However, governance issues involving the management and distribution of benefits flows and the wealth generated from mining operations have impacted on the delivery of essential services and expectations of landowners.

\section{Minerals and mining policy}

Prior to 1989, PNG's minerals and mining policy was directed at the distribution of resource rent, mineral rights and sovereign risk assessment. ${ }^{9}$ Landowners were not directly involved in negotiations concerning major resource development; they were merely consulted and then their interests were presented in the negotiation process. Benefits to landowners, if any, were set out in contracts, such as the Mining (Bougainville Copper Agreement) Act 1967 or the Mining (Ok Tedi Agreement) Act 1976, between the state and the developer. This policy applied to all major commercial projects, regardless of the nature of the landowners' stake in the project, until after the Bougainville conflict, when the government undertook a review of the minerals and mining policy. The review led to the introduction of the new Mining Act 1992. The Mining Act 1992 and the Petroleum Act 1992, now the Oil and Gas Act 1998, provide for consultation ${ }^{10}$ and development forum ${ }^{11}$ processes involving landowners, and provincial and local-level governments. This was to ensure that the views of persons affected by project proposals are considered and thus help to minimise disputes in relation to projects. Landowners now negotiate how benefits from major projects will be distributed during a development forum process ${ }^{12}$ and the agreements reached lead to the state and landowners to the signing of specific agreements (Memorandum of Agreement (MOA)) confirming the terms of their benefit sharing arrangements and obligations to ensure delivery and continuation of the security of the project. Under an MOA, ${ }^{13}$ benefits are provided in: (i) royalties - revenue allocated to the provincial government (hosting the project) $;^{14}$ (ii) special support grants (SSG) - grants allocated to the provincial government (host province) as budget support for infrastructure development (deliver goods and services to the project area, and facilitate the development and operation of the project) $;^{15}$ and (iii) state equity - 22.5 per cent from petroleum projects $^{16}$ and 30 per cent from mining projects, ${ }^{17}$ a share of which is also allocated to the provincial government hosting the project to support the development of infrastructure, and delivery of goods and services.

\section{Case studies}

While there is now an approach that aims to share benefits from the exploitation of natural resources, and customary landowners are given more status in the negotiation of benefits as new natural resource projects are developed, it is not necessarily the case that there are improvements in the livelihood of the customary landowners or that their expectations are fulfilled. ${ }^{18}$ More governance initiatives are required to ensure that there is equitable distribution of benefits and to ensure that all citizens are empowered to participate in social and economic development, as enshrined in the Constitution. ${ }^{19}$ Various factors, for example, lack of service delivery due to weak public capacity to implement expenditure plans, including on key essential social

\footnotetext{
Power, above n 4, 86-7.

9 Colin Filer, 'Resource Rents' in Ila Temu (ed), Papua New Guinea: A 20/20 Vision (National Centre for Development Studies, Research School of Pacific \& Asian Studies, ANU, Pacific Policy Paper 20, 1997) 225; M Taylor and K Whimp, 'Report on Land Issues and Hydrocarbon Framework Study' (Port Moresby: Fuels and Energy Management Group for Department of Petroleum and Energy, 1997) 19.

${ }^{10}$ Mining Act 1992 (PNG), s 3 - Consultation; Organic Law on Provincial Government and Local-Level Government, s 116 Consultation.

${ }^{11}$ Oil and Gas Act 1998 (PNG), s 48 - Development Forum.

12 Banks, above n 6, 24-25 [4]

${ }^{13}$ Mining Act 1992 (PNG), s 16A - Acquisition of State Interests.

${ }^{14}$ Oil and Gas Act 1998, s 159 - Royalty.

${ }^{15}$ Oil and Gas Act 1998, s 173 - Project Grants.

${ }^{16}$ Oil and Gas Act 1998, s 165 - State Equity Entitlement.

17 Mining Act 1992, s 16A - Acquisition of State Interests.

${ }^{18}$ Carolyn Fischer, 'International Experience with Benefit-Sharing Instruments for Extractive Resources' 2007 (May) Resources for the Future 38.

${ }^{19}$ Constitution of the Independent State of Papua New Guinea 1975, Preamble - National Goals and Directive Principles (Goals Nos 1 to 5 ).
} 
services, such as health, education and infrastructure ${ }^{20}$ and transparency and accountability in the management and distribution of benefits ${ }^{21}$ are being highlighted as reasons for the short-fall in meeting landholders' expectations.

It is the aim of this paper to use the case studies of the Porgera and Lihir gold mines to illustrate the issues that affect management of revenues and distribution of benefits from the exploitation of natural resources in PNG. The paper concludes with suggestions on how PNG could better manage and benefit from its natural resource wealth.

\section{Porgera Gold Mine}

The Porgera Gold Mine is located at the head of the Porgera Valley, Enga Province. It is the second largest mine in PNG and contributes about 12 per cent to PNG's GDP. ${ }^{22}$ The Porgera project development agreements were negotiated under the Mining Act 1992, under which the state involved and consulted the provincial and local-level governments and landowners; however, the state retained its sovereign right to negotiate the development contract with the developer. ${ }^{23}$ Agreements reached led to the state, Enga Provincial Government and Porgera landowners entering into a MOA on benefit sharing.

\section{Development agreements}

A number of agreements were negotiated and used as a guide for the operation of the mine through to its closure, and how benefits were to be distributed. These agreements included: Relocation Agreement; Compensation Agreement; Tripatite Agreement and a Mining Development Contract. The MOAs were signed between the state, Enga Provincial Government and Porgera landowners in May 1989. A Mining Development Contract was also signed between the state and the Developer. ${ }^{24}$ The benefit sharing arrangements concern royalty payments: (1) 13 per cent to Special Mining Lease (SML) - landowners and children; (2) 10 per cent to Porgera Development Authority, and Enga Provincial Government to receive 'Special Support Grant' of 1 per cent of the mine production in the first ten years. This agreement has been subjected to several reviews but the concept of distribution of benefits remains. ${ }^{25}$ An addition to the list of beneficiaries is the Porgera Landowners Association, now a major beneficiary of benefit flows.

\section{Distribution of benefits}

The Porgera Gold Mine has produced approximately PGK (Kina or K) 16.4 billion. Approximately K6.4 billion in benefits has been distributed to several groups and institutions: ${ }^{26}$ Porgera Landowners - K1 178901394 ; Porgera Development Authority (PDA) - K130 212 706); Enga Provincial Government - K278 916 164, Enga Province - K424 378 635, National Government - K1 712897426 . However, although these benefits have purportedly been paid, there is a lack of transparency and accountability ${ }^{27}$ related to their equitable management and distribution of the benefits. ${ }^{28}$

\footnotetext{
${ }^{20}$ Aaron Batten, 'Service Delivery and Resource Revenues in PNG' on PNGBlogs (29 June 2011) <http://devpolicy.org/service-delivery-and-resource-revenues-png20110629/Service Delivery and Resource Revenues in PNG>.

${ }^{21}$ Stuart Kirsch, 'Property Effects, Social Networks and Compensation Claims in Melanesia' (2001) 9(2) European Association of Social Anthropology 147, 156; K Afosa, 'Financial Reporting in the Mining Sector: The Case for Landowner Reports in Papua New Guinea' (2005) 15(36) Australian Accounting Review 89, doi:10.1111/j.1835-2561.2005.tb00296.x; Glenn Banks, 'Landowner Equity in Papua New Guinea's Mineral Sector: Review and Policy Issues' (2003) 27(3) Natural Resources Forum 224; Banks (2008) above n 6, 31-32; M Macintyre, Wendy Mee and Fiona Solomon, 'Evaluating Social Performance in the Context of an “Audit Culture”: A Pilot Social Review of a Gold Mine in Papua New Guinea', (2007) 15(2) Corporate Social Responsibility and Environmental Management 100, 106 [2], doi:10.1002/csr.155; Susan Toft, 'Patrons or Clients? Aspects of Multinational Capital-Landowner Relations in Papua New Guinea' in Susan Toft (ed), Compensation for Resource Development in Papua New Guinea (Law Reform of Papua New Guinea, Monograph No 6, and Resource Management in Asia and the Pacific Research School of Pacific \& Asian Studies, ANU and the National Centre for Development Studies, ANU, 1997) $12-13$

${ }^{22}$ Greg Anderson (ed), Papua New Guinea Chamber of Mines and Petroleum Profile 2013, (PNG Chambers of Mines and Petroleum, $12^{\text {th }}$ ed, 2012), 113.

${ }^{23}$ Filer, above n 9, $240[1]$.

${ }^{24}$ Peter Johnson, 'Lode Shedding: A Case Study of the Economic Benefit to the Landowners, the Provincial Government and the State, from the Porgera Gold Mine: Background and Financial Flows from the Mine' (National Research Institute Discussion Paper No 124, 2012) 7.

${ }^{25}$ Colin Filer and Benedict Imbun, 'A Short History of Mineral Development Policies in Papua New Guinea, 1972-2002' in R J May (ed), Policy Making and Implementation: Studies from Papua New Guinea (ANU E Press, 2009) Ch 6.

${ }^{26}$ Johnson, above n 24, 10-12.

27 Ibid 88 [8].

28 Ibid.
} 
The method of distribution and diligence of allocation is not effective, and landowners are not satisfied with the management of benefits. There is an absence of due diligence in record keeping, including lack of data on how the funds are distributed and projects implemented. Lack of information and data on the method of distribution makes it difficult to ascertain just how much and where the funds have gone and who has been paid. It is equally difficult to ascertain the impact of project funds on the communities and province generally. ${ }^{29}$ For example, the PDA has not provided any information on how the benefits are being used, which has led to landowners disputing the amount of benefits flows from the project as promised by the developer. Lack of information also makes it difficult for the beneficiaries to know and understand exactly what amount of funds is being spent by the leaders in their community and on what. ${ }^{30}$ Thus, while the Porgera Mine has paid different government institutions and landowner groups royalties, levies and development grants under the MOA, it is clear that 'government institutions on the ground are not doing what they were expected to do' and 'these accounts are managed by faceless people'. ${ }^{31}$ Hence, for those landowners and communities who should be benefiting from the mineral wealth, the payment arrangement system makes it difficult to keep a concise and credible trail of these payments; transactions are such that there is a payment to an agency and, from there, the benefit disappears, not reaching the intended recipient.

Lack of transparency at all levels of government, ${ }^{32}$ including weaknesses in the government's operating, accounting and auditing system, have encouraged the misuse of benefits for purposes outside of the agreed arrangement. In addition, failure in reporting the details of payments from and to mining project stakeholders $^{33}$ leads to distrust by landowners of developers. For example, the Porgera Landowners Association (PLOA), formed to represent landowners from surrounding traditional lands around the Porgera Gold Mine, ${ }^{34}$ has failed to serve the interests of landowners, and information on PLOA's financial performance is limited. ${ }^{35}$

\section{Expectations of landowners}

Royalty payments to the PLOA to 2010 amount to K16 500 000.00, about 12 per cent of the mine's royalties. ${ }^{36}$ However, as already noted, there are disputes as to where these funds have been invested or who has control over the funds due to lack of accounting and transparent disclosure; a significant amount of royalties are untraceable and unaccounted for.$^{37}$ No accountability has been enforced and the lack of transparency has led to much mistrust ${ }^{38}$ by landowners of the way the funds are being distributed. No audit of PLOA accounts has been undertaken despite efforts by landowners for access to this information. ${ }^{39}$ Company records are also not updated. Many landowners complain that embezzlement of royalty payments is common and that ordinary landowners are not benefiting. ${ }^{40}$

\section{Lihir Gold Limited}

Lihir Gold Limited (LGL) operates an open pit mine on Niolam Island in the New Ireland Province, ${ }^{41}$ PNG. Like the Porgera Mine, Lihir contributes about 12 per cent to PNG's GDP. ${ }^{42}$ The benefit-sharing arrangements negotiated for the Lihir landowners and local communities catered for an integrated benefits package which included payments of funds derived from the mine, royalties and special support grants, direct compensation arrangements, and a number of community, social and infrastructure development programs ${ }^{43}$ in a number of ways, including direct revenues from operations, investments in public infrastructure and services, support of local suppliers and a range of indirect economic benefits. ${ }^{44}$ LGL is now wholly owned by Newcrest Ltd in a

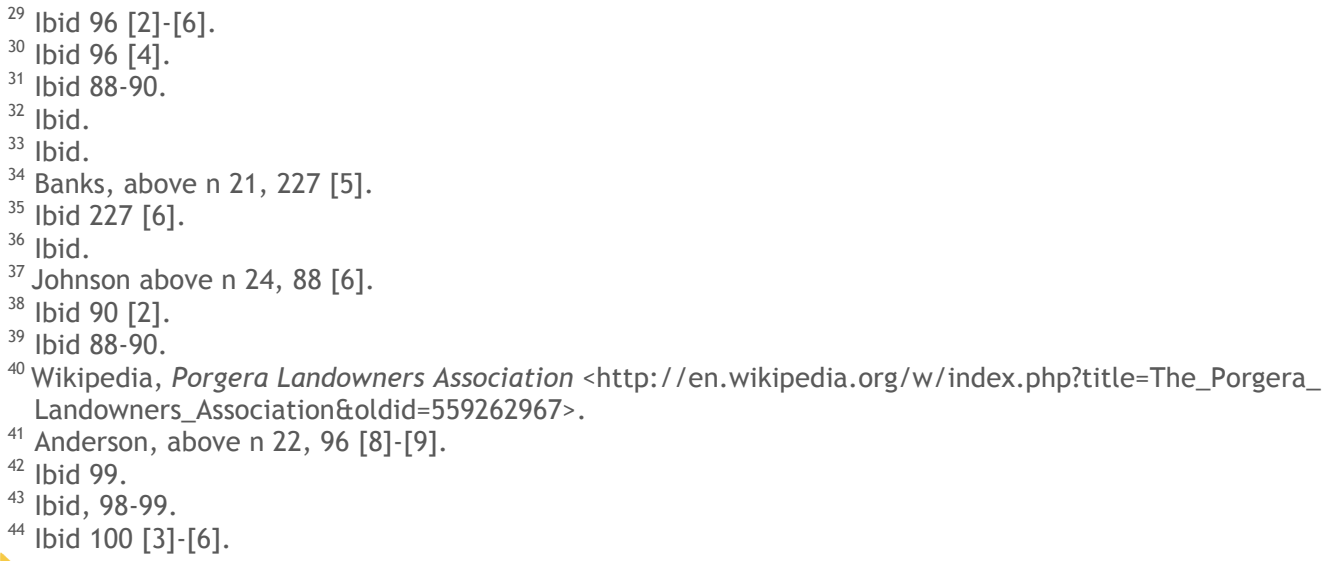


court-approved arrangement. ${ }^{45}$ However prior to this takeover, when negotiations for the development of the Lihir project commenced, the project proponent, Lihir Gold Ltd, was owned by a number of shareholders, including Rio Tinto, Orogen Minerals and Mineral Resources Lihir (which is a landowner company holding equity on behalf of the Lihir landowners). ${ }^{46}$

\section{Development agreement}

The negotiations for benefit sharing arrangements between the landowners, the state and mining company covers compensation, royalties, business development and an option that would allow landowners to acquire equity ${ }^{47}$ in the project. Following agreement on the benefit sharing arrangements, a MOA was signed between the state, Lihir Mining Area Landowners Association (six landowning clans) and the Nimamar Development Authority (local government business arm) on 26 April 1995. The agreement contained the following benefit sharing arrangements: ${ }^{48}$ (i) Option for Lihirians to take up 15 per cent equity in participation in the initial Lihir Joint Venture (equity to be held on its behalf by the Mineral Resources Development Authority (MRDC) based on the price that MRDC would pay for Mineral Resources Lihir to participate in the joint venture); (ii) in addition to the 15 per cent equity, the state offered to use its best endeavours to secure a further option to purchase 5 per cent at market value of the shares offered in the market for Lihir Gold Ltd. ${ }^{49}$ However these shares were to be purchased by the landowner company from its own pocket and were not subject to the terms of the original 15 per cent ${ }^{50}$ equity in the company.

According to a deed of settlement for the Lihir Equity Trust, any surplus dividends (after repayment of loans and interest) would be distributed to the following beneficiaries: (i) 50 per cent of such to be used for funding of projects in education, health and infrastructure ${ }^{51}$ to assist communities within the Lihir group of Islands, or, alternatively, funds can be used to purchase rights in Lihir Gold Ltd; and (ii) 50 per cent to be distributed in individual payments by cheque to every 18 year-old male and female Lihirian. ${ }^{52}$

\section{Distribution of benefits}

Following a corporate re-structure of the company in 2005, Mineral Resources Lihir sold its shares for purposes of repaying a loan which MRDC had taken out on its behalf to purchase its equity stake in Lihir gold. Mineral Resources Lihir is now operating as a legal entity under its own name, MRL Capital Limited (MRLC), ${ }^{53}$ which is the investment arm of the Lihir landowners company. ${ }^{54}$ MRL Capital now has a total asset base worth over K600 000000 and owns a subsidiary company, MRL Pty Ltd, which is listed on the Australian and PNG Stock Exchange ${ }^{55}$ with close to 50 per cent of its portfolio made up of income assets, including cash, short-term deposits and fixed interests, and a property portfolio both in PNG and Australia. ${ }^{56}$

Another direct beneficiary of the Lihir Gold Mine development is the Anitua Group of Companies. The Anitua Group of Companies is a shareholder company comprising of six clans from the Lihir Islands and includes the local-level government business arm. The company was established to enable the landowners to participate in the business spin-off from the Lihir gold development project. This landowner group has grown to become the largest single suppliers of goods and services to Lihir Gold Ltd and is looking at expanding their services to other sectors within PNG, ${ }^{57}$ an aspect that makes the Group stand out from the Porgera Landowners Association, which is struggling to make an impact on the lives of landowners and communities in Porgera area. The Anitua Group of Companies has been involved in a range of business activities and with a range of different. It partners has activities which includes offering packages of services in project construction, camp management, security, mining services and more. The Group's impressive portfolio of businesses includes: Anitua Constructions; Anitua Corporate Services; Anitua Farms; Anitua Hardware; Anitua Investments; Anitua

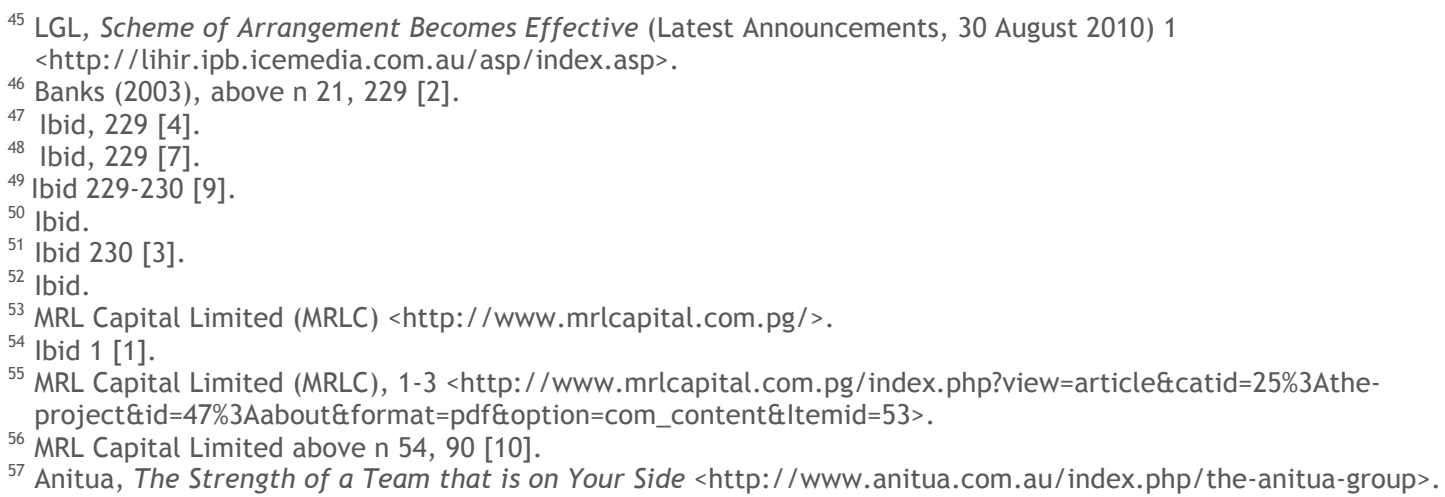


Mining Services; Anitua Properties; Anitua Radial Drilling Services; Anitua Security Services; Anitua Supermarket; Anitua Transport Services; Lihir Auto Services; Lihir Investments (Australia) and NCS Holdings. ${ }^{58}$

For the Lihir landowners, the distribution of benefits to landowners has worked and the landowner companies have built in an investment structure and made sustainable use of their dividends, noting the risks that landowners take in equity participation in resource projects.

\section{Expectation of landowners}

The Lihir landowners believe that their interests are paramount and investment decisions are targeted towards the protection, preservation and growth in their investments for the benefit of more than 14000 of its clan members. The landowners' primary focus is to build an investment portfolio that will be able to support them after closure of the mine. ${ }^{59}$

\section{Issues that affect better management and distribution of benefits}

Revenues generated from exploiting rich natural resources can greatly increase funding for social service delivery. However, issues such as weak public sector capacity to implement expenditure plans, including funding for key items such as health, education and infrastructure,$^{60}$ continue to inhibit delivery of social services. With few exceptions (eg, the Lihir case study described above), there appears to be no control over what programs are funded and who gets paid. There is no efficient and transparent system of accounting and auditing mechanisms. To benefit from the exploitation of its resources, PNG must establish a system of management that addresses issues of land tenure, claims for compensation and equity participation. In addition, PNG must introduce a public finance system which is transparent in how benefits are distributed. ${ }^{61}$ In other words, PNG must establish a governance systems aimed at improving performance, transparency and accountability in the management of wealth acquired through the exploitation of its natural resources. ${ }^{62}$ Establishing measures in all levels of government to ensure that institutions have the checks and balances mechanisms necessary to guard against bad behaviour ${ }^{63}$ would assist in the governance and management of revenue generated and the distribution of benefit flow. Legal instruments exist, such as the Public Finance Management Guidelines and Procedures (Pubic Finance Management Act 1995), ${ }^{64}$ Public Service Commission (Public Service General Orders - Public Services (Management) Act 1995) ${ }^{65}$ and the Ombudsman Commission (Organic Law on the Duties and Responsibilities of Leadership ${ }^{66}$ (Leadership Code)). However, for these instruments to be effective in arresting bad behaviour and increasing financial accountability, ${ }^{67}$ responsible institutions must be appropriately funded and empowered.

In particular, the Public Service General Orders are Codes that govern the conditions and terms of employment contracts and disciplinary processes of all public servants (excluding Departmental Heads) employed by the state, must be used to police bad behaviour, including nepotism ('wantok system'). ${ }^{68}$

Overall, a review of the laws and procedures relating to matters of benefit sharing should be undertaken to determine how systems could be improved to enhance accountability, governance and transparency in governance by responsible institutions. It is necessary for government to create a systematic audit trail of payments from mining companies to all parties: national, provincial and local governments, and landholders,

\footnotetext{
58 Ibid.

59 LGL, above n 46, 1

${ }^{60}$ Batten, above n 20.

${ }^{61}$ Afosa, above n 21; Banks (2003), above n 21, 224 [4]; Banks (2008) above n 6, 31-32 [5]; Macintyre et al, above n 21; Toft, above n 21; Kirsch, above n 21.

${ }^{62}$ Australian Agency for International Development, 'The Economy of Papua New Guinea: Macroeconomic Policies: Implications for Growth and Development in the Informal Sector' (Economic Insights Pty Ltd, International Development Issues, No 53, June 1999) 47-50 [9].

${ }^{63}$ Australian Agency for International Development, 'Papua New Guinea: The Role of Government in Economic Development, International Development’ (Economic Insights Pty Ltd, Issues No 33, 1994) 132.

${ }^{64}$ Public Finance (Management) Act 1995 (PNG) s 5 - Responsibilities of Heads of Departments, s 6 - Accountable Officers, s 7 Responsibility of Public Office-Holder in Relation to Collection of Revenue, and s 8 - Finance Inspectors, s 11- Keeping of Public Account.

${ }^{65}$ Public Services (Management) Act 1995 (PNG), s 13 - Powers of the Commission and s 18 - Review of Personnel Matters Connected with the National Public Service.

${ }^{66}$ Organic Law on the Duties and Responsibilities of Leadership, s 13 - Misappropriation of funds of Papua New Guinea,

${ }^{67}$ Australian Agency for International Development (1994) above n 64, 132-6.

68 Ibid.
} 
and government should ensure that the roles and responsibilities of beneficiaries are properly demarcated so that policies for the delivery of social services are implemented, managed, monitored, evaluated and audited at the local level ${ }^{69}$ This initiative would increase the accountability and governance of these institutions and the implementation of approved developmental projects. ${ }^{70}$ With regard to the identity of beneficiaries, a review and amendment to sections 12 and 13 of the Civil Registration Act $1963^{71}$ requiring mandatory registration of all births, marriage and deaths of Papua New Guineans would greatly assist government to establish the identity all members of a clan, tribe or community, and to determine eligibility to benefits from a resource development. Registration can lead to minimising fraudulent claims for compensations and resource benefits as well as determine allocations for infrastructure programs. Overall, it will enhance accounting and auditing of benefits and financial flows, and minimise disputes relating to ownership claims and transaction costs, as well as ensuring that benefits are equitably distributed to the impacted landowners within PNG. ${ }^{72}$

\section{Recommendations}

The Porgera and Lihir landowner groups took into consideration a number of common factors when negotiating for benefits in a resource development forum. These matters involved payments for royalties, equity participation, re-location and re-settlement, compensation for future generation, and social and environmental impacts. However, there is great disparity in the governance of the management and distribution of benefit flows between the two cases: the Lihir landowners group of companies are investing their benefits and reaping returns, but there is not much information on the benefit flows for the Porgera landowners. Why is there so much disparity? The difficulty faced by Porgera landowners is that there is no reporting and accounting of how much benefit is paid and where it is spent? There is no audit of the company records, which is complicated by the fact that there is no mandatory legal requirement to file company records. In addition, it is difficult to pinpoint where accountability lies; is it at the time that proposals for projects or services are made or is it when appropriating or implementing projects. In both cases, there is no requirement for the landowner groups to invest their newly acquired wealth. The landowners are left to determine their own destiny. Is it government's responsibility to establish and ensure that these entities comply with some regulatory framework and procedures in the management and distribution of benefits? Currently there appears to be no government processes to keep track of the payments of benefits.

However, it is encouraging to see that the Lihir landowner companies are determined to make every investment profitable for their shareholders and for future generation in anticipation of the eventual closure of the mine. Although some investments are risky, the Lihir landowners are hopeful and currently enjoying their benefits. The Lihir landowner companies provide a good example of what can be achieved.

To encourage better management of benefits derived from the development of natural resources by all groups in PNG, the government needs to streamline the governance of natural resources. There must be due process and accountability in decision-making processes to ensure that distribution of benefits significantly improves the lives of the beneficiaries and the country as a whole, and to eliminate conflicts of interests. Landowners must be empowered to invest their benefits in a range of economic projects or become equity participants in projects. To produce such streamlining requires a reform of government policies and regulations governing the development of the natural resource and distribution of benefits.

Overall, the Organic Law on Provincial and Local-Level Governments, Mining Act 1992 and Oil and Gas Act 1998, respectively incorporate participation and eligibility for provincial and local-level governments, and affected landowners to negotiate benefit flows from the development of natural resource projects on their land or proximity to their land. These entitlements or benefits are integrated into the current system of distribution of benefits between the national and provincial governments, and landowners from the impacted resource areas ${ }^{73}$ using the formula for benefit sharing arrangements ${ }^{74}$ prescribed under both the Mining Act $1992^{75}$ and the Oil and Gas Act $1998 .^{76}$ These laws have the potential to ensure good benefit sharing but governance arrangements inhibit their proper implementation.

\footnotetext{
${ }^{69}$ Banks (2003) above n 21, 223 [1].

70 Johnson, above n 24, 88-90.

${ }^{71}$ Civil Registration Act 1963 (PNG), s 12 - Establishment of Compulsory Registration Areas and Prescribed Premises.

${ }_{72}^{72}$ Australian Agency for International Development, above n 64, $12-13$ [5].

73 Anderson, above $\mathrm{n} 22,4$ [3]

74 Ibid.

${ }_{75}^{75}$ Mining Act 1992 (PNG), s 16A- Acquisition of State interests.

${ }^{76}$ Oil and Gas Act 1998 (PNG), s 159 - Royalty, s 173 - Project Grants and s 165 - State Equity Entitlement.
} 